UK), $0.25 \mu \mathrm{M}$ control primers, $0.5 \mathrm{U}$ DNA polymerase (Advanced Biotechnologies, Epsom, UK), and $50 \mathrm{ng}$ genomic DNA. One duplicate reaction set was specific for the normal sequence $(845 \mathrm{G})$ and a second reaction set was specific for the mutated sequence $(845 \mathrm{~A})$; both reaction sets used a common forward primer (5'-AAGGTGACACATCATGTGACC-3'), with a reverse primer specific for either 845G (5'-CTGGGTGCTCCACCTGGC-3'), or $845 \mathrm{~A}$ (5'-CTGGGTGCTCCACCTGGT-3'), resulting in a PCR product of 232 base pairs. Control primers, which amplified an 842 base pair fragment of the human growth hormone gene ${ }^{8}$ were included in all reactions. Amplification conditions involved an initial denaturation step for one minute at $96^{\circ} \mathrm{C}$, followed by five cycles consisting of denaturation for 25 seconds at $96^{\circ} \mathrm{C}$, annealing for 45 seconds at $70^{\circ} \mathrm{C}$, and extension for 30 seconds at $72^{\circ} \mathrm{C}$, then a further 21 cycles where the annealing temperature was lowered to $65^{\circ} \mathrm{C}$, plus four cycles where annealing was for one minute at $55^{\circ} \mathrm{C}$, and extension was for two minutes at $72^{\circ} \mathrm{C}$. A final extension step for five minutes at $72^{\circ} \mathrm{C}$ completed the amplification.

\section{Results and discussion}

The duplicate reaction sets typing for either $845 \mathrm{G}$ or $845 \mathrm{~A}$ were analysed by electrophoresis on a $1.5 \%$ agarose gel; PCR products were visualised by staining with ethidium bromide and photographed under ultraviolet illumination. Results from three representative individuals are shown in fig 1 . The results demonstrate that the PCR-SSP method is highly specific for the haemochromatosis associated mutation $845 \mathrm{G} \rightarrow \mathrm{A}$ in the HFE gene and that the method could be used as an aid to diagnosis, or for screening purposes.

I am very grateful to Dr Mark Worwood (Department of Haematology, University of Wales College of Medicine) for his kind gift of DNA for validation purposes. Primers were designed from sequence data for the haemochromatosis gene deposited in Genbank (Accession number U60319).

1 Simon M, Bourel M, Fauchet R, Genetet B. Association of $\vec{O}$ HLA-A 3 and HLA-B14 antigens with idiopathic haemoHLA-A3 and HLA-B14 antigens
chromatosis. Gut 1976;17:332-4.

2 Bodmer JG, Parham P, Albert ED, Marsh SGE. Putting a hold on 'HLA-H'. Nat Genet 1997;15:234-5.

3 Feder JN, Guirke A, Thomas W, Tsuchihashi Z, Ruddy DA, Basava A, et al. A novel MHC class I-like gene is mutated in patients with hereditary haemochromatosis. Nat Genet 1996;13:399-408.

4 Jazzing Powell LW, et al. Haemochromatosis and HLA-H. Nat Powell LW, et al. Haemochromatosis and HLA-H. Nat o
Genet 1996;14:249-51.

5 Jouanolle AM, Gandon G, Jézéquel P, Blayau M, Campion 윽 $\mathrm{ML}$, Yaouanq J, et al. Haemochromatosis and HLA-H. Nat Genet 1996;14:251-2.

6 Beutler E. Genetic irony beyond haemochromatosis: clinical effects of HLA-H mutations. Lancet 1997;349:296-7.

7 Miller SA, Dykes DD, Polesky HF. A simple salting out procedure for extracting DNA from human nucleated cells. cedure for extracting DNA from

8 Guttridge MG, Burr C, Klouda PT. Identification of HLA$\mathrm{B} 35, \mathrm{~B} 53, \mathrm{~B} 18, \mathrm{~B} 5, \mathrm{~B} 78$ and B17 alleles by the polymerase chain reaction using sequence-specific primers (PCRSSP). Tissue Antigens 1994;44:43-6.

\title{
High resolution single strand conformation polymorphism analysis using formamide and ethidium bromide staining
}

\author{
T Xie, S L Ho, O C K Ma
}

University

Department of

Medicine, University

of Hong Kong, Hong

Kong

T Xie

S L Ho

Department of Clinical Biochemistry

$\mathrm{O} \mathrm{C} \mathrm{K} \mathrm{Ma}$

Correspondence to:

Dr Ho, University

Department of Medicine,

University of Hong Kong

Queen Mary Hospital, Hong

Kong.

Accepted for publication 14 August 1997

\begin{abstract}
Single strand conformation polymorphism (SSCP) analysis using ethidium bromide can be improved by adding formamide as the denaturant. This gives higher resolution than previous SSCP methods; it had $100 \%$ sensitivity in the discrimination of 14 PCR samples from two different genes, even for a long fragment close to the upper limit of 250 base pairs. This modified procedure is a rapid, simple, safe, and yet highly sensitive method for detecting structural differences in DNA fragments.

(F Clin Pathol: Mol Pathol 1997;50:276-278)
\end{abstract}

Keywords: single strand conformation polymorphism; formamide; ethidium bromide
Polymerase chain reaction (PCR) amplifica $\omega$ tion of DNA fragments followed by single strand conformation polymorphism (SSCP) analysis is a sensitive method for detecting $\stackrel{?}{+}$ genetic polymorphisms or mutations. Detection by autoradiography ${ }^{1}$ or silver staining ${ }^{2}$ is time consuming, costly, and inconvenient. Non-isotopic SSCP (cold SSCP) using ethid- $\stackrel{\mathbb{2}}{2}$ ium bromide staining ${ }^{34}$ facilitates the rapid identification of structural changes in PCR 8 products. Currently, the denaturant used most frequently in cold SSCP is either sodium hydroxide $^{4}$ or methylmercury hydroxide. ${ }^{3}$ The $\stackrel{?}{?}$ former has been reported in some cases to yield inconsistent results ${ }^{3}$; the latter is an extremely toxic and volatile compound ${ }^{5}$ and great care has to be taken to avoid skin contact with methylmercury and inhalation of its aerosol. 

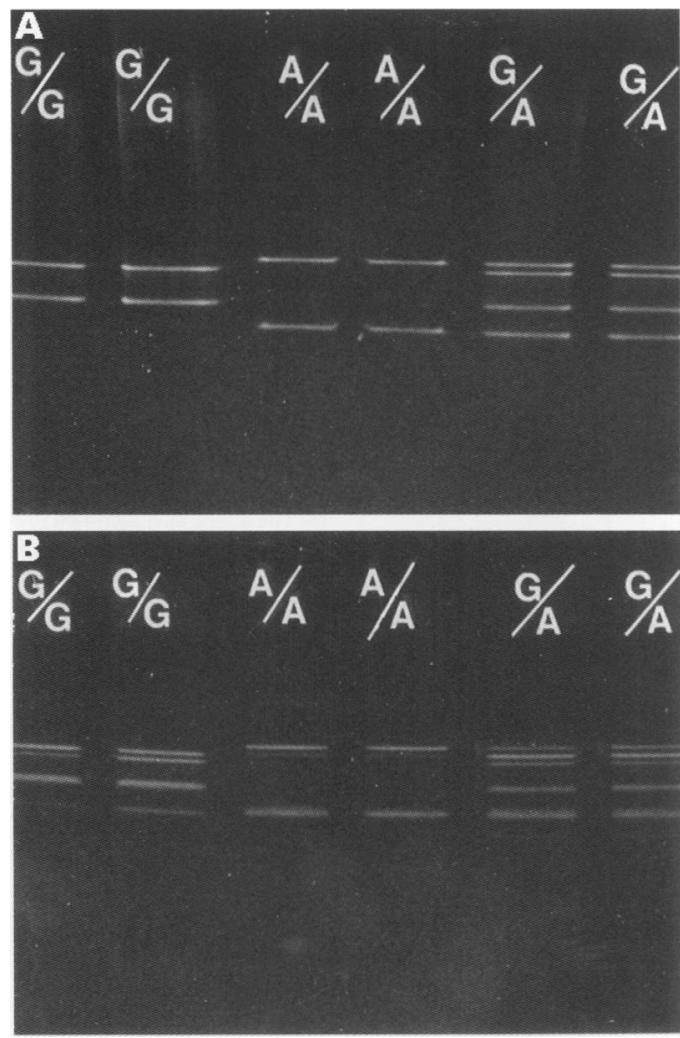

Figure 1 SSCP analysis of the human catechol $O$-methyltransferase gene; $(A)$ with formamide and $(B)$ without formamide. Three pairs of PCR products (from left to right) from individuals homozygous for $G / G$ and $A / A$ (each with two bands of ssDNA) and heterozygous for $G / A$ (four bands of ssDNA) with different mobility shifts. The various bands showed a high resolution in $(A)$ and a lower resolution with additional artefactual bands in (B).

Therefore, it is desirable to find an alternative denaturant that gives a high resolution but is less toxic.

Formamide has been used previously as the denaturant in the silver staining method for SSCP $^{6}$ but not in ethidium bromide staining. Silver stained SSCP analysis has high resolution but there is a brown or yellow background caused by non-specific deposition of insoluble silver salts. ${ }^{7}$ Hence, we hypothesised that formamide might maintain the high resolution of bands without the background stain, if it were used with ethidium bromide instead of

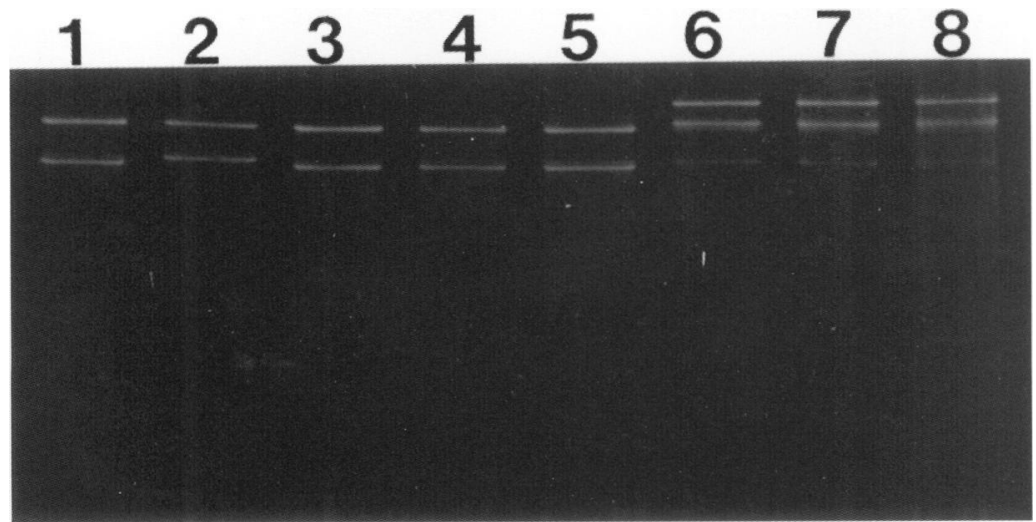

Figure 2 SSCP analysis of the p53 gene using formamide as the denaturant. Eight PCR products comprising 184 base pairs were derived from different cell lines with known single base mutations. All of them were detected successfully by different mobility shifts as shown. Lane 1: cell line $S W 480(G \rightarrow A$ mutation at codon 273, positive control); lane 2: cell line 915 (no mutation, negative control); lanes 3, 4, and 5: cell lines 666, 1915, and Met 1, respectively $(G \rightarrow A$ mutation at codon 273$)$; lanes 6,7 , and 8: cell lines $C N E 1, C N E 2$, and Sune-1, respectively ( $G \rightarrow C$ mutation at codon 280 ). silver. In this paper, we compared the sensitivity of SSCP analysis using formamide and sodium hydroxide as a denaturant in ethidium bromide stained polyacrylamide gels.

\section{Methods}

We tested 14 PCR products amplified from two different genes: six from the human catechol O-methyltransferase gene and eight from human $\mathrm{p} 53$, a tumour suppressor gene.

The catechol O-methyltransferase gene has a polymorphism at codon $1947(\mathrm{G} / \mathrm{G}$, or $\mathrm{A} / \mathrm{A}$, or $\mathrm{G} / \mathrm{A})$ that is associated with high or low activity of the enzyme in erythrocytes. The forward and reverse primers used were: 5'CTGCACAGGCAAGATCGTGGA-3' and 5'-TCCAGGTCTGACAACGGGTCA-3', respectively. The optimal PCR conditions were: primers $(25 \mu \mathrm{M})$, genomic DNA $(0.1-0.4 \mu \mathrm{g})$, dNTPs $(0.2 \mu \mathrm{M}), \mathrm{MgCl}_{2}(2 \mu \mathrm{M})$, and use of the "hot start" PCR at $94^{\circ} \mathrm{C}$ for five minutes before adding Taq polymerase ( 1 unit; Advanced Biotechnologies, Epsom, Surrey, UK); then $94^{\circ} \mathrm{C}$ for one minute, $65^{\circ} \mathrm{C}$ for 30 seconds, $72^{\circ} \mathrm{C}$ for 30 seconds, for 26 cycles, and a final extension time of five minutes at $72^{\circ} \mathrm{C}$. The amplified fragment length was 234 base pairs.

The PCR product (volume $10-15 \mu \mathrm{l} ; 20$ $100 \mathrm{ng}$ of DNA) was mixed with an equal volume of sequencing stop buffer containing $98 \%$ formamide. The other constituents were $10 \mathrm{mM} \mathrm{NaOH}, 20 \mathrm{mM}$ EDTA, $0.05 \%$ bromophenol blue, and $0.05 \%$ xylene cyanol. A control experiment was carried out simultaneously with $10 \mathrm{mM}$ sodium hydroxide and no formamide. No purification of the PCR product was necessary before SSCP analysis when only one desired major band was present. The mixture was denatured at $100^{\circ} \mathrm{C}$ for seven minutes then plunged into ice immediately for five minutes. Next, the mixture was loaded on to a $20 \%$ Tris borate EDTA (TBE) polyacrylamide gel $(8.0 \times 8.0 \times 0.1 \mathrm{~cm} ; 39: 1$ acrylamide: bisacrylamide; Novex, San Diego, California, USA). Electrophoresis was carried out in $1.5 \times$ TBE buffer, initially at $400 \mathrm{~V}$ for two minutes, followed by $300 \mathrm{~V}$ for 2.5 hours, using the thermoflow system (Novex) and refrigerated circulator (Pharmacia Biotech, Uppsala, Sweden) to maintain consistent temperature. Different running temperatures ranging from $10^{\circ} \mathrm{C}$ to $25^{\circ} \mathrm{C}$ were tried, and the optimal temperature was found to be $15^{\circ} \mathrm{C}$ for this particular fragment. After electrophoresis, the gel was stained with a $0.5 \mu \mathrm{g} / \mathrm{ml}$ solution of ethidium bromide for 20 minutes, then washed with water for five minutes. Ethidium bromide stained bands were visualised using a $340 \mathrm{~nm}$ ultraviolet viewing box and photographed with an exposure time of one second.

We also tested detection of a single base mutation ( $\mathrm{G} \rightarrow \mathrm{A}$ and $\mathrm{G} \rightarrow \mathrm{C}$ mutations) in exon 8 of the human p53 tumour suppressor gene, using a further eight PCR products and similar conditions (except using a running temperature of $20^{\circ} \mathrm{C}$ ). 


\section{Results}

We found that formamide denatured gels showed better resolution than those denatured using sodium hydroxide alone (fig 1); better even than any other published pictures. Although sodium hydroxide also showed some different mobility shifts in SSCP, gel lanes often showed additional artefactual bands comprising incomplete denatured single strands, which made it difficult to detect the polymorphic bands (fig 1B). In contrast, the use of formamide as a denaturant did not result in any ambiguity and gave high resolution in distinguishing the various alleles (fig 1A) of the polymorphic region tested.

Others ${ }^{67}$ have used different volume ratios of formamide to PCR product (3:1 or 1:1) in silver stained SSCP. We did not find any difference in the resolution of the ethidium bromide stained SSCP using volume ratios of $1: 1,2: 1$, or $3: 1$. We found that a $1: 1$ volume ratio was the most practical because of the limited well volume of the gel. We also compared various concentrations of sodium hydroxide (ranging from a final concentration of 10 $50 \mathrm{mM}$ ) as denaturants in our cold SSCP analyses but did not find any significant difference in the resolution (data not shown). Different gel concentrations of $6 \%$ and $20 \%$ homogeneous polyacrylamide TBE gels, and 4-20\% gradient polyacrylamide gels (Novex) were used: we found that the $20 \%$ homogeneous polyacrylamide TBE gel demonstrated the best resolution of this polymorphism.

In addition, this method detected and distinguished all the other known single base mutations in exon 8 of the human p 53 gene within the eight PCR products tested (fig 2).

\section{Discussion}

To our knowledge, this ethidium bromide stained cold SSCP procedure using formamide as the denaturant has not been reported before. It gave a higher resolution than previous SSCP methods and had $100 \%$ sensitivity in the discrimination of 14 PCR samples from two different genes, even for a long fragment close $z$ to the upper limit of 250 base pairs. We believe 으 that this modified procedure is a rapid, simple, safe, and yet highly sensitive method for $?$ detecting structural differences in DNA frag- $\overrightarrow{\vec{s}}$ ments.

This work was sponsored by the Committee on Research and Conference Grants, University of Hong Kong. We are grateful for the space and facilities provided by Professor E D Janus (the Clinical Biochemistry Unit, Queen Mary Hospital) and for the $\mathcal{C}$ critical review of this manuscript by Dr Joan Marsh (Clinical $\vec{\circ}$ Trials Centre, The University of Hong Kong). The PCR prod- . ucts of the human p53 tumour suppressor gene were kindly provided by $\mathrm{Dr} \times \mathrm{H}$ Yang (department of microbiology, $\omega$ University of Hong Kong).

1 Orita M, Iwahana $H$, Kanazawa $H$, Hayashi $K$, Sekiya $T$. Detection of polymorphisms of human DNA by gel i electrophoresis as single-strand conformation polymor- N phisms. Proc Natl Acad Sci USA 1989;86:2766-70.

2 Dickhorn-Dworniczak B, Dworniczak B, Brommelkamp L, O Bulles J, Horst J, Bocker WW. Non-isotopic detection of single strand conformation polymorphism (PCR-SSCP): a rapid and sensitive technique in diagnosis of phenylketonuria. Nucleic Acids Res 1991;19:2500

3 Hongyo T, Buzard GS, Galvert RJ, Weghorst CM. "Cold 음 SSCP": a simple, rapid and non-radioactive method for ( optimized single-strand conformation polymorphism optimized single-strand conformation polymorphism $\vec{c}$ analyses. Nucleic Acids Res 1993;21:3637-42.
Yap EPH, McGee JOD. Nonisotopic SSCP detection in PCR products by ethidium bromide staining. Trends Genet 1992;8:49.

5 Sambrook J, Fritsch EF, Maniatis T. Electrophoresis of RNA through agarose gels containing methylmercuric hydroxide. In: Sambrook J, Fritsch EF, Maniatis T, eds. O Molecular cloning: a laboratory manual, 2nd edn. New York: Cold Spring Harbour Laboratory Press, 1989:731-2.

6 Ainsworth PJ, Surh LC, Coulter-Mackie MB. Diagnostic single strand conformational polymorphism, $\vec{O}$ (SSCP): a simplified non-radioisotopic method as applied to a Tay-Sachs B1 variant. Nucleic Acids Res 1991;19:4056.

7 Peng H, Du M, Ji J, Isaacson PG, Pan L. High-resolution SSCP analysis using polyacrylamide agarose composite gel and a background-free silver staining method. Biotechniques 1995;9:411-14. 